A M E R I C A N

\title{
J OURNAL OF INSANITY.
}

\begin{tabular}{lll}
\hline \hline VOL. XVIII. & OTICA, OCTOBER, 1861. & No. 2. \\
\hline
\end{tabular}

ESSAYS, CASES, AND SELECTIONS.

\section{SHAKSPEARE'S DELINEATIONS OF MENTAL IMBECIL- ITY, AS EXHIBITED IN HIS FOOLS AND CLOWNS. \\ By A. O. Kellogg, M. D., Port Hope, Canada West.}

In former papers in this journal, we have attempted to point out the extraordinary accuracy and facility manifested by the great dramatist in the delineation of mind as warped and influenced by disease, and to show that in drawing the characters of Lear, Macbeth, Lady Macbeth, Ophelia, and Hamlet, he has exhibited a knowledge of the operations of mind, as influenced by delicate shades of disease far beyond that of his own times, and quite equal to that of the most accomplished psychologists of our own. Nothing connected with the operations of the human intellect, in any forms, whether of health or disease, seems to have escaped the observation of this " myriad-minded" man, nothing has been too high for his sublime and philosophical contemplation, nothing too low for h.s minute and careful observation. $\mathrm{He}$ has traversed the whole realm of human intellect, as a sovereign prince makes a triumphal tour through a conquered province; while philosophers and moralists, physicians and metaphysicians, statesmen, lawgivers, and poets, have fallen humbly at his feet to do him

Vol. XVIII. No. 2. 
homage; for in the province of each he has been acknowledged worthy to reign supreme. In that of the physician and medical psychologist, we think we have given sufficient evidence of his deserved supremacy, in former papers, and what is applicable to this our peculiar province, we believe to be applicable to all, and that proof of this would not be difficult to furnish.

To multiply instances, and bring forward illustrations, would not come within the scope of these papers. One illustration however we are tempted to adduce in this place, which must suffice. So great was Shakspeare's knowledge of law-forms and law-terms (see Lord Campbell, cum multis aliis) that nearly every lawyer who reads Shakspeare carefully, is ready to maintain that the poet must have been a lawyer, or at least a law student at some period of his life, and as one once remarked to the writer, was only driven from the legal profession into poetry and the drama by the force of his great genius. If the validity of such evidence is to be admitted in proof of his having been a lawyer, we see no reason why, on the strength of the proofs we have adduced in former papers in this journal, we should not be allowed to claim that the great bard must once have been a physician to the insane; for we think we have shown conclusively that he understood insanity in all its varied forms; and perhaps it would not be more difficult to show that Shakspeare was once physician in chief to Bedlam Hospital, than to establish many other things that have been asserted respecting his earthly career. Such for example, as his horse grooming and his deer stealing.

But, unlike our brethren of the law, we seek to set up no special claim to him as one of our number, but content ourselves with regarding him as the common property of all thinkers in each and every department of literary effort and scientific research; and proceed at once to consider another phase of this great intellectual luminary of the sixteenth century, viz : his delineations of the innumerable shades of mental obtuseness and mental imbecility in the characters of his fools and clowns.

In the illustration of the varied and innumerable shades of folly, mental obtuseness, and mental imbecility naturally incident to hu- 
manity, our poet is incomparably rich, and every degree and order of mental manifestation is represented with a truthfulness and vigor which has never been equaled, and perhaps never will be to the end of time. He has given us a type of everything bearing the shape of humanity, however remote, and the class of characters we now have to consider, like all his others, do not stand up before us as creatures of the imagination, but as real bodily existences, and we cannot divest ourselves of the idea that such must at some period of time, have walked or "crawled between the heavens and earth." Many of them we have seen, and those that we have not, we feel that we might and should have seen "if our eyes had been opened" like those of the poet.

Of imbeciles and clowns-fools as they are generically termed-he has an almost endless variety, and the very names which he gives them are sometimes so strikingly significant and characteristic, that the mere mention of them forces a smile.

Let us take a few examples by way of introduction, and see if we can suppress a smile when the mere name of some of them is called out from the presentation rôle. Bottom the weaver, Peter Quince the carpenter, Snug the joiner, Snout the tinker, Flute the bellowsmender, Starvling the tailor, Christopher Sly the tinker, Sir Toby Belch, Sir Andrew Ague-cheek, Froth, Dogberry, Malvolio, Launcelot Gobbo, Touchstone, Simple, Slender, Shallow, Speed, Dull, Costard, Caliban, Elbow, Lucio, Moth, Mouldy, Shadow, Feeble, Bullcalf and Wart, and lastly, as the curious procession rnust end somewhere, comes Launce, leading his interesting dog Crab.

Here we have presented to us a galaxy of fools such as is nowhere else to be found, and every shade of folly, imbecility and mental obtuseness is represented, and the portraiture of each as delineated by the bard, is well worthy of the cognomen bestowed.

First in the motley procession we see Bottom the weaver, the very embodiment and quintessence of self-conceit, and of everything, in short, necessary to constitute a perfect human ass. It was not sufficient for him to simply be "writ down an ass" in the record, like Dogberry, but the diadem which crowned him prince of all his tribe

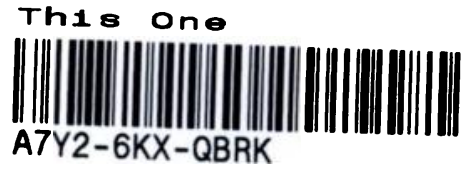


must be placed in due form upon his head, and when first led in by Puck after his coronation, the poet must certainly have chuckled over his own workmanship, and said quietly to himself-" 0 , all ye tribes of human asses, that are, ever have been, or ever will be, behold your king ! from this time henceforth and forever, let no one of you deny my anointed." And to all posterity he seems yet to say, "Behold the perfection of conceited blockheads, the asinorum asinalissimus, par excellence! From henceforth and forever let no man dispute $m y$ workmanship. Doubt if you will that moonshine can be personated by a man holding a lantern behind a thorn bush; that a lion can modulate his voice so sweetly that he shall roar you as 'twere any nightingale or sucking dove; that a wall can be personated by a man plastered over with lime and rough cast,-but while Bottom, wearing his ass's head, can, by his conceit which makes all things possible, believe this, let no one deny that he is the crowned and anointed king of Donkeys."

And by what a court is this strange potentate surrounded, and worshipped !

First we see Peter Quince, the carpenter and playwright. If Bottom is prince of donkeys, Quince takes the first place of honor in his court and is prince of playwrights, and his title, like that of Bottom, cannot be disputed.

0 ! all ye tribes of playwrights, wherever ye are ; ye Knowles's, and Shees, and Maturins ; ye Gillparzers, Klingemanns and Kotzebues; many of you cunning men in your handicraft, behold your king, Peter Quince, the anointed of the poet! And whosoever he anoints and crowns let none of you seek to depose.

And you, ye " periwig-pated players," who, whether amateur or professional, can " tear a passion to tatters," to very rags; ye who are capable of nothing but inexplicable dumb show, and noise to "split the ears of the groundlings ;" who " strut and bellow, having neither the accent of Christians nor the gait of Christians, pagans or men,-products of nature's journeymen," those " mechanics who " imitate nature so abominably," remember your great antecessors, 
those histrionic mechanicals of the poet, Snug the joiner, Starvling the tailor, Flute the bellows mender, and Snout the tinker.

So extensive, varied and rich is Shakspeare in his illustrations of the almost endless forms of mental imbecility, that it would be impossible to give each more than a passing glance in this connection. He has taken his subjects for portraiture from all ranks and grades of life, high and low, rich and poor, and almost every trade, profession and calling has furnished him subjects, and having glanced at such as he has selected from his own calling, the histrionic, we pass on to take a view of his official imbeciles.

Of this class of mental impotents we hardly know which to select to head the list; whether Dogberry, Justice Shallow, or some other, as each seems to claim pre-eminence. With all due deference to others, however, we consider we shall not go far astray in selecting the first.

Dogberry is not so much an imaginary character as a type of a class of bungling judicial impotents to be found in real life, and through whose clumsy and cowardly imbecility many a thief has escaped the penitentiary, and many a murderer the gallows. The backwoods of Canada, and the outskirts of civilization in all new countries, furnish too many such. A justice of this kind who, by his cowardly and bungling imbecility, had allowed the chief of a trio of murderers to escape, we once saw in the witness-box at a court of Assize, held before one of the most learned and eloquent judges on the bench; and the answers to the questions put to him by his Lordship, would have done ample justice to Dogberry himself. "Is it possible," said the Judge, at the conclusion of his examination of the witness, "that you are a justice of the peace of this province ?" "Yes, and I has been for more as fifteen years, your Lordship," was the reply. "God help the country," said the learned Judge, as he dismissed him contemptuously from the stand. Shakspeare, with a few vigorous touches of his never-failing pencil, has given us a full-length portrait of such a character as this in Dogberry. (See Much Ado About Nothing, Act III, Scene 3, and Act IV, Scene 2.) 
Genius, it is said, is quick to detect genius, and the unerring certainty with which it selects its instruments has often been remarked, Stupidity, it would seem, is governed by the same local law. See how Dogberry selects his constable :

Dogberry. "First, who think you the most desartless man to be constable?

1 Watch. "Hugh Oatcake, sir, or George Seacoal; for they can write and read.

Dogberry. * * * "To be a well-favored man is the gift of fortune; but to write and read comes by nature.

"Well, for your favor, sir, give God thanks, and make no boast of it ; and for your writing and reading, let that appear when there is no need for such vanity. You are thought here to be the most senseless and fit man for the constable of the watch; therefore bear you the lantern. This is your charge. You shall comprehend all vagrom men; you are to bid any man stand, in the prince's name.

2 Watch. "How if 'a will not stand?

Dogberry. "Why, then, take no note of him, but let him go; and presently call the rest of the watch together, and thank God you are rid of a knave.

"You shall also make no noise in the streets; for, for the watch to babble and talk the streets, is most tolerable and not to be endured.

2 Watch. "We will rather sleep than talk; we know what belongs to a watch.

Dogberry. "Why, you speak like an ancient and most quiet watchman; for I can not see how sleeping should offend; only, have a care that your bills are not stolen.-Well, you are to call at all the ale-houses, and bid those that are drunk get them to bed.

2 Watch. "How if they will not?

Dogberry. "Why, then, let thern alone till they are sober; if they make you not then the better answer, you may say, they are not the men you took them for.

"If you meet a thief, you may suspect him, by virtue of your office, to be no true man; and, for such kind of men, the less you meddle or make with them, why, the more is for your honesty.

2 Watch. "If we know him to be a thief, shall we not lay hands on him?

Dogberry. "Truly, by your office you may; but I think they that touch pitch will be defiled. The most peaceable way for you, if you do take a thief, is, to let him show himself what he is, and steal out of your company."

The downright stupidity, ignorance and donkeyism, shown in 
Act III, Scene 5, and the ludicrous misuse and misconception of terms peculiar to worthies of the Dogberry and Verges stamp, is rich in the extreme.

Leonato. "What is it, my good friends?

Dogberry. "Goodman Verges, sir, speaks a little of this matter -an old man, sir, and his wits are not so blunt as, God help, I would desire they were; but, in faith, honest as the skin between his brows.

Verges. "Yes, I thank God, I am as honest as any man living, that is an old man and no honester than I. ges.

Dogberry. "Comparisons are odorous; palabras, neighbor Ver-

Leonato. "Neighbors, you are tedious.

"It pleases your worship to say so," says Dogberry, (evidently not comprehending the term tedious, but mistaking it for a commodity of value,) " but we are the poor duke's officers; but, truly, for mine own part, if I were as tedious as a king, I could find in my heart to bestow it all on your worship.

Leonato. "All thy tediousness on me! ha !

Dogberry. "Yes, and 'twere a thousand times more than 'tis;" etc.

The following as a sample of driveling senile imbecility, can scarce be matched, and is from the mouth of Dogberry, where he speaks of Verges, and in which (quite oblivious, of course, as to his own stupidity) he patronizingly and with great self-satisfaction bewails the infirmities of his brother official.

Dogberry. "A good old man, sir; he will be talking; as they say, When the age is in, the wit is out ; God help us ! It is a world to see !-Well said, i'faith, neighbor Verges :-well, God's a good man ; and two men ride of a horse, one must ride behind. An honest soul, i'faith, sir; by my troth, he is, as ever broke bread; but God is to be worshipped. All men are not alike; alas ! good neighbor !"

When Leonato reminds him that indeed his friend comes very far short of himself, what self-satisfaction and conceit is embodied in his short reply.

" Gifts," says he, "Gifts that God gives !" quite unconscious that his greatest gift is like that conferred on Bottom; the gift of an ass's head.

But the climax of bungling imbecility, ignorant officiousness and 
self-conceit, we havo in Act IV, Scene 2, where Dogberry presides at the court of inquiry held over Conrade and Borachio; and the laughable record of proceedings, in which every thing is so curiously jumbled together-where every thing which is impertinent is carefully noted down, and every thing incident to the inquiry as carefully excluded, and where terms the most dissimilar are confounded-furnishes, in its way, a model of judicial procedure. The first blunder he makes is simply the confounding of hirnself and his brother official with the culprits to be examined before him :-

Dogberry. "Is our whole dissembly appeared ?***

Sexton. "Which be the malefactors?

Dogberry. "Marry, that am I and my partner.

Verges. "Nay, that's certain; we have the exhibition to examine."

After duly recording the names of his prisoners, the first question he puts to them is certainly most pious and pertinent, considering the characters he is supposed to address :-

"Masters," says he, " do you serve God?

Con. \& Bora. "Yes, sir, we hope.

Dogberry. "Write down-that they hope they serve God;and write God first; for God defend but God should go before such villains !'

The idea soon strikes the sexton that the proceedings are somewhat informal, and that witnesses and proof were necessary.

Sexton. "Master constable, you go not in the way to examine ; you must call forth the watch that are their accusers."

Dogberry, whose dignity is hard to offend, and who is totally unsuspicious that any one should ever presume to question his knowledge and intelligence, seizes at once upon the suggestion, as though it was something of minor importance, however, that had escaped him in the most casual way. He says :-

Dogberry. " Yea, marry, that's the eftest way.-Let the watch come forth.-Masters, I charge you, in the prince's name, accuse these men."

The first witness testifies that one of the prisoners called Don John a villain. Dogberry immediately orders Don John to be put down 
a villain in the record, and pronounces the calling a man villain flat perjury. Another witness testifies that the other prisoner had declared that he received a thousand ducats from Don John for accusing a lady wrongfully. "Flat burglary," says Dogberry, " as ever was committed."

Verges. "Yea, by the mass, that it is. ***

Dogberry. "O villain! thou wilt be condemned into everlasting redemption for this."

The sexton suggests that the prisoners be bound and removed. Dogberry, acting upon the hint, immediately orders them to be "opinioned," when one of thern, resisting, calls him a coxcomb. This does not seem greatly to disturb his equanimity. Perhaps, as usual, he does not fully comprehend the import of the word coxcomb ; for he calls the prisoner simply a naughty varlet, and orders the sexton to write down the prince's officer a coxcomb in his extraordinary record of procedure. The other prisoner is more clear and explicit. The term he applies to Dogberry is by no means ambiguous. "You are an ass," says he, emphatically, and repeats it, "You are an ass." The term ass Dogberry has no difficulty in comprehending the import of; that is quite clear, and he immediately throws himself back upon his offended official dignity, and the terms in which he asserts this are most ludicrously characteristic :-

Dogberry. "Dost thou not suspect my place? Dost thou not suspect my years? - 0 that he were here to write me down an ass ! -But, masters, remember that I am an ass ; though it be not written down, yet forget not that I am an ass. - No, thou villain, thou art full of piety, as shall be proved on thee by good witnesses. I am a wise fellow; and, which is more, an officer; and, which is more, an householder; and, which is more, as pretty a piece of flesh as any in Messina ; and one that knows the law, go to; and a rich fellow enough, go to; and a fellow that hath had leases; and one that hath two gowns, and every thing handsome about him.-Bring him away. O that I had been writ down-an ass!"

Another official of the Dogberry stamp we have in constable Elbow, in Measure for Measure. As with Dogberry, much of the humor of this character rests upon his ridiculous misuse and misconception of the most common terms.

Vol. XVIII. No. 2. 
Elbow. "If it please your honor, I am the poor duke's constable, and my name is Elbow. I do lean upon justice, sir, and do bring in here before your honor two notorious benefactors.

Angelo. "Benefactors? Well, what benefactors are they? are they not malefactors?"

The meek simplicity of the reply, and the donkey-like unconsciousness with which he contradicts himself, is worthy of the most accomplished of our poet's long-eared officials.

Elbow. "If it please your honor, I know not what they are : but precise villains they are, that I am sure of; and void of all profanation in the world, that good Christians ought to have."

A little farther on he makes other most ludicrous blunders in the use of the king's English ; which blunders aided by the humour of the clown, are nearly calling in question the character of his own wife. When Elbow is asked by Escalus by what authority he gives the clown and his employer, mistress Over-done, such an infamous character, he replies:

"My wife, sir, whom I detest (protest) before heaven," \&c. "I say, sir, I will detest myself, also, as well as she, that this house, if it be not a bawd's house, it is a pity of her life, for it is a naughty house."

"First and it like you, the house is a respected (suspected) house ; next, this a respected fellow; and his mistress is a respected woman.

Clown. "By this hand, sir, his wife is a more respected person than any of us all.

Elbow. " Varlet thou liest ; thou liest, wicked varlet; the time is yet to come, when she was ever respected with man, woman, or child.

Clown. "Sir, she was respected with him, before he married with her.

Elbow. " $O$ thou caitiff! $O$ thou varlet! $O$ thou wicked Hannibal! I respected with her before I was married to her! If ever I was respected with her, or she with me, let not your worship think me the poor duke's official ;-Prove this, thou wicked Hannibal, or I'll have my action of battery on thee."

This whole scene in Measure for Measure, (Act II, Scene 2,) is exceeding rich in illustration of our subject. The amusing circumlocution of the clown in telling his story in defence from the charge brought against him by Elbow, is exceedingly characteristic, but as 
we propose to return to him in treating of this class of characters in subsequent papers, we pass him by for the present.

The next worthy we select from our list of imbeciles, is Shallow, or, as he designates himself and is described by his scarcely less interesting cousin Slender, Robert Shallow, Esquire, in the county of Gloster, just:ce of the peace and coram, and custalorum, and ratolorum, a gentleman born, who writes himself armigero in all warrants, obligations, \&c., and has done so any time these three hundred years, as all his successors gone before him have done, and all his ancestors that come after him may do, as with other worthies of his class in real life, who have " a plentiful lack of wit," a plentiful supply of titles and cheap honors is necessary to complete their personality. If nature is sometimes niggardly in her gifts, fortune steps in to make in her way ample restitution, and a " plentiful lack" of brains is compensated by a plentiful supply of bonds, and the lack of wit and wisdom by " land and beeves." Among worthies of this class, Robert Shallow, Esquire, of Gloster, holds an eminently respectable, if not honorable position; and though his antecedents, as given by Falstaff, are not the most flattering, as we shall see, this matters little. Like other " respectables," he is only under the necessity of remembering such as are suited to his present circumstances and condition in life.

Shallow, like a true scion of a genuine English family of parvenues, has gone through the forms necessary to a liberal education. He has shown above that he has some Latin, and when Bardolph tells him that the soldier Falstaff is better accommodated than with a wife, he adds, after a little circumlocution: "Accommodated, that comes of accommodo; very good, a good phrase." What little Latin he has, he is ready to display upon every convenient, and sometimes inconvenient occasion, like all superficials. Like his cousin William, he may have been at Oxford to the great " cost" of some one, bringing home with him, as the natural fruit of this " cost," a cherished and ever abiding remembrance of his wildness and folly. "I was once," says he, "at Clement's Inn, where I think they will talk of mad Shallow yet." 
How very natural is the boasting which follows! It might have come from the mouth of any one " of all the kind" of the Shallows, as well as from Robert Shallow, Esquire, of Gloster :-

"By the mass, I was called anything; and I would have done anything, indeed, and roundly too. There was I, and little John Doit, of Staffordshire, and black George Bare, and Francis Pickbone, and Will Squele, a Cotswold man,-you had not four such swingebucklers in all the inns of court, again ; and I may say to you, we knew where all the bona-robas were, and had the best of them all at commandment."

The crouching obsequiousness and lack of dignified self-respect in their intercourse with superiors in rank and station in life, so characteristic of all the family of the Shallows, wherever found, (and every one must have met some of them in the journey of life,) is admirably delineated in the scene where he bores Falstaff with his vain, officious and bustling hospitality; a hospitality based entirely upon vanity, and a desire to show off his own importance, and to " have a friend at court."

Shallow. "Nay, you shall see mine orchard, where in an arbour, you will eat a last year's pippin of mine own graffing, and a dish of carraways, and so forth."

The silly affectation of his reply to the knight's compliment to his rich dwelling is also quite characteristic: "Barren, barren, barren; beggars all, beggars all, sir John !"

Notwithstanding this affectation of poverty and beggary, it is plain to all, and to none more so than Falstaff, that the Shallows are a thriving family. If he is an adept in finesse, Shallow is infinitely his superior in finance and domestic economy; shrewdness in these matters, is, as a rule, quite characteristic of the Shallows, wherever they are found. Indeed, the most wordly thoughts are apt to creep in and disturb their most solemn musing; sometimes it is to be feared, their very devotions. When Silence reminds Shallow of the uncertainty of life, he replies:

"Certain, 'tis certain, very sure, very sure; death, as the Psalmist saith, is certain to all ; all must die. How a good yoke of bullocks at Stamford fair ?" 
Even in the midst of his exciternent at the arrival of the " manof-war" and his suite, and his bustling endeavors to entertain them suitably to his own dignity, and their importance as coming from the court, he can stop to give directions in matters of business and domestic economy to his man Davy :-

"Marry, sir, thus;-those precepts can not be served : and, again, sir,-Shall we sow the headland with wheat?

Shallow. "With red wheat, Davy? ***

Davy. "Yes, sir.-Here is now the smith's note for shoeing, and plough-irons.

Shallonv. "Let it be cast, and paid.-Sir John, you shall not be excused.

Davy. "Now, sir, a new link to the bucket must needs be had. -And, sir, do you mean to stop any of William's wages, about the sack he lost the other day at Hinckley fair?

Shallow. "He shall answer it," \&.c.

How descriptive is all this of a class of characters to be met with every day; they are fools, and acknowledged to be such by the world, yet in money transactions and matters of domestic economy they are "wise as serpents." And yet in these matters of finance and economy their serpent wisdom is sometimes no match for the hawk-eyed vigilance and shrewd wit of some spendthrift, who, taking them in an unguarded moment, and understanding well their weak points, by a stroke of policy relieves them in a moment of the hard earnings and niggardly savings of years, as Falstaff relieved Justice Shallow of his thousand pounds.

Who is there that has not met some one or more of this family of Shallows? It is a known fact in psychology that a man may be "stark mad" on one or two subjects, and to all appearances quite sound on others. Upon precisely the same psychological principles we may suppose that a man may be wise on some one or two subjects, and in the sense in which the term is applied to Shallow, a fool on all others. Indeed our experience and observation of life teach us that it is so.

Another characteristic of the Shallows is admirably illustrated in Act V, Scene 1, viz., their manner of dealing with domestics and dependents. Towards the weak, like William who lost the sack, 
they are overbearing and cruel, while unconsciously to themselves they are completely ruled and led captive by those who are cunning, and strong of will and purpose, like Davy, who in reality is the justice in all but name, and on such familiar terms with his nominal master that he presumes to dictate the manner in which he is to dispense his judical favors.

Davy. "I beseech you, sir, to countenance William Visor of Wincot, against Clement Perkes of the hill.

Shallow. "There are many complaints, Davy, against that Visor; that Visor is an arrant knave, on my knowledge.

Davy. "I grant your worship that he is a knave, sir; but yet, Heaven forbid, sir, but a knave should have some countenance at his friend's request. An honest man, sir, is able to speak for himself, when a knave is not. I have served your worship truly, sir, these eight years; and if I can not once or twice in a quarter bear out a knave against an honest man, I have but a very little credit with your worship. The knave is mine honest friend, sir; therefore, I beseech your worship, let him be countenanced.

Shallow. "Go to; I say, he shall have no wrong," \&c.

But for a climax to every description of the character of Justice Shallow we must resort to Falstaff. It would be impertinent to look for such elsewhere. The fat knight, whose brain was by nature as plethoric of wit and wordly wisdom as was the rest of his huge body of capons, sack and sugars, measures at once the mental calibre of the lean justice, and the depth of his purse, and shapes his course accordingly. "I do see the bottom of Justice Shallow," says he; and if he had never told a greater lie, or made a more unreasonable boast, he would never have been Jack Falstaff. But let us come at once to his descriptive climax of Justice Shallow:

"If I were sawed into quantities, I should make four dozen such bearded hermit's-staves as master Shallow. It is a wonderful thing to see the semblable coherence of his men's spirits and his; they, by observing of him, do bear themselves like foolish justices; he, by conversing with them, is turned in a justice-like serving man; their spirits are so married in conjunction with the participation of society, that they flock together in consent, like so many wild geese. If I had a suit to master Shallow, I would humour his men, with the imputation of being near their master; if to his men, I would curry with master Shallow, that no man could better command his servants. It is certain that either wise bearing or ignorant carriage, is 
caught as men take diseases, one of an other; therefore, let men take heed of their company. I will devise matter out of this Shallow, to keep prince Harry in continual laughter, the wearing out of six fashions, (which is four terms, or two actions,) and he shall laugh without intervallums. 0 , it is much, that a lie with a slight oath, and a jest with a sad brow, will do with a fellow that never had the ache in his shoulders. ***

"Lord, lord, how subject we old men are to this vice of lying. This same starved justice has done nothing but prate to me of the wildness of his youth, and the feats he hath done about Turnbull street; and every third word a lie, duer paid to the hearer than the Turk's tribute. I do remember him at Clement's inn, like a man made after supper of a cheese-paring; when he was naked he was for all the world like a forked radish, with a head fantastically carved on it with a knife; he was the very genius of famine, yet lecherous as a monkey. * * He came ever in the rearward of the fashion, and sung those tunes to the over-scutched huswives that he heard the carmen whistle, and sware they were his fancies, or his good nights. And now is this Vice's dagger become a squire; and talks as familiarly of John of Gaunt as if he had been sworn brother to him ; and I'll be sworn he never saw him but once in the Tiltyard ; and then he burst his head for crowding among the marshal's men. I saw it, and told John of Gaunt, he beat his own name ; for you might have thrust him and all his apparel into an eel-skin; the case of a treble hautboy was a mansion for him, a court; and now hath he land and beeves. Well, I will be acquainted with him, if I return ; and it shall go hard but I will make him a philosopher's two stones to me. If the young dace be a bait for the old pike, I see no reason in nature but I may snap at him. Let time shape, and then an end."

We have barely entered upon the list of the poet's imbeciles, and yet we are at the end of our space, and hope upon a future occasion to return to this highly interesting as well as amusing class of characters.

To the psychologist, every shade of mental manifestation, whether high or low, strong or weak, normal or abnormal, is alike interesting and worthy of careful observation. 